\title{
SOME SOIL PROPERTIES AS INFLUENCED BY DIFFERENT QUALITY OF IRRIGITION WATER UNDER SUB-SURFACE DRIP IRRIGATION SYSTEMES \\ Habib, M. F. ${ }^{1}$; M. E. Ali ${ }^{1}$; M.A. Awad ${ }^{1}$ and M. S. S. Abdel Hai ${ }^{2}$. \\ 1: Faculty of Agriculture, Benha University, Egypt. \\ 2:Soil, Water and Environment, Research Institute (SWERI), Agricultural Research Center (ARC) Giza, Egypt.
}

\begin{abstract}
The objective of the current study was demonstrate the effects of using subsurface drip irrigation systems with fresh Nile water and treated wastewater on the growth of Bermuda grass (Cynodon dactylon) and some soil properties. To achieve these aims, a field experiment was carried out at the experimental farm of the Central laboratory for environmental quality Monitoring in Delta Barrage (El_Qanatir), Cairo, Egypt. The area of study was cultivated with Hybrid Bermuda grass and the experimental design was split-plot design with the source of irrigation water in the main plots i.e. treated wastewater and fresh Nile water and the irrigation systems in the sub-plots.

The results reveal that treated wastewater can be used successfully with subsurface drip irrigation systems. The use of treated wastewater with drip irrigation systems increased the concentration of salt in soil profile. However, no harmful impacts were detected on the growing grass. Finally, application of treated wastewater by sub-surface drip irrigation system may be used safety from the point of view of the concentration of heavy metal.
\end{abstract}

Keywords: wastewater - Bermuda grass-drip irrigation system- soil properties.

\section{INTRODUCTION}

The increasing needs for irrigation water in the arid areas of the world has resulted in the use of wastewater for agriculture and landscaping. The use of non-conventional water resources and opportunities for achieving food security in water-scarce countries was amply justified (Qadir et al., 2007).

El Zaemey (1992) reported that during the last decade wastewater, recycling and reuse in agriculture has received much attention around the world especially in arid and semi-arid regions. Where there are estimated 2.4 billion- $\mathrm{m}^{3}$ years ${ }^{-1}$ of sewage, which represents a significant burden on the environmental pollution caused by human activity and practices (ECP 501, 2005).

Holy (1971) showed that the quality of irrigation water is usually evaluated with respect to the yields from agricultural crops. However, the requirements of irrigation water are much broader because the society is aware of the fact that this water may pollute surface- and ground waters used for various purposes. The irrigation water enters directly the food chain; it is used for the preparation of foodstuffs.

American Society of Agricultural Engineering (ASAE) (2005) defined subsurface drip irrigation as the application of water below the soil surface through emitters, with discharge rates typically in the same range as drip irrigation. 
Regardless of the type of subsurface drip system, the same basic components are used and can be segregated into three categories: (1) filter station, (2) PVC pipelines, and (3) drip tape. The filter station is composed of a water pressure source (e.g., deep well turbine, booster pumps, centrifugal pump reservoir setups, etc.), screen and/or media filters, injection pumps, and irrigation controllers (Trenton, et al., 2008).

Subsurface irrigation systems can reduce the need for costly wastewater treatment, protect against environmental contamination and enhance efficient water use for many crops. This system provides better control of the application rate and distributes effluent uniformly, thereby minimizing groundwater contamination risks. Agricultural irrigation with industrial wastewater is a common practice in arid and semiarid regions and it is used as a readily available and inexpensive option to scarce fresh water, (Shock, 2007).

Abou-El-Soud (2009) stated that subsurface drip irrigation received the lowest depths of water applied, stored and consumed and consequently it achieved the highest irrigation application efficiency. Using traditional surface irrigation; gated pipes and single surface drip lateral systems achieved the lowest ECe values in soil, while subsurface drip irrigation single surface drip lateral and double surface drip laterals systems recorded the highest ECe values.

The current investigation aims at investigating the impact of irrigation systems and type of irrigation water on the soil using the following indicators: soil moisture and salt distribution and movements; relationship between electrical conductivity (EC) and both of soil depth and time and the rate of growth of the cultivated grass (plant height and intensity).

\section{MATERIALS AND METHODS}

\section{Laboratory experiments:}

Laboratory experiments were conducted to obtain the most appropriate distance between the lines of drip irrigation and the most suitable distance between drippers. The most suitable distance between drippers long track is $25 \mathrm{~cm}$ and sub-irrigation lines buried at a depth of $20 \mathrm{~cm}$ below the soil surface and the distance between the sub-irrigation lines 0.5 meters. This study was conducted on the landscaping planted grass (Bermuda grass). For each tested emitter the emission uniformity was measured under two levels of operating pressure, namely 50 and $100 \mathrm{Kpa}$. The tested emitters were long path (GR) $50 \mathrm{~cm}$ of emitter spacing, long path (GR) $25 \mathrm{~cm}$ distance and leaky pipe. The highest value of emission uniformity (EU) was observed with long path emitter and leaky pipe emitter, which were 96.03 and $97.0 \%$ respectively.

A field experiment was conducted at Residential and Industrial Wastewater Treatment System located in the National Water Research Center, Central Laboratory for Environmental Quality Monitoring in Delta Barrage (El_Qanatir), Cairo, Egypt. The experimental area was planted by Hybrid Bermuda grass and lasted for one-year beginning with January to December. The field experiment was divided into two main experiments; the first irrigated by treated wastewater, while the other one was irrigated by fresh 
Nile water. The experiment was laid out in a split-plot design with two main plots in two separate locations indicating the source of irrigation water i.e. Nile water and treated wastewater. Each main plot contained two sub- plots indicating the irrigation type i.e. subsurface drip irrigation system with long path emitter, and subsurface drip irrigation system with leaky pipe. Some chemical analyses of the treated wastewater and fresh Nile water, which were determined according to the standard methods, cited by Page et al., (1982) are presented in Table 1. Physical and chemical properties of the soil used in the experiment were determined according to the standard methods cited by Klute (1986) and Page et al., (1982) are presented in Table 2.

The irrigation System design:

a- Subsurface drip irrigation with long path emitter: the system consists of eight laterals line $(\varphi 16 \mathrm{~mm})$ with $25 \mathrm{~m}$ length. The experimental area was $100 \mathrm{~m}^{2}(4 \times 25)$. The laterals were provided with the required number of emitters spaced $25 \mathrm{~cm}$ apart on the lateral. The distance between laterals was $50 \mathrm{~cm}$ and the lateral was buried at depth of $20 \mathrm{~cm}$ beneath the soil surface.

b- Subsurface drip irrigation with leaky pipes: the dimension of this system of irrigation and the experimental area was as in subsurface drip with long path emitter. The two-sub surface drip systems were similar in lateral spacing and emitter spacing but they differed only in the emission device, which was the leaky pipe that applied a wit strip of water during the irrigation operation.

Table 1. Physicochemical and microbiological of the used water.

\begin{tabular}{|c|c|c|}
\hline Parameters & $\begin{array}{c}\text { Treated } \\
\text { wastewater }\end{array}$ & $\begin{array}{c}\text { Fresh } \\
\text { Nile water }\end{array}$ \\
\hline$E C\left(d S m^{-1}\right)$ & 0.85 & 0.33 \\
\hline $\mathrm{pH}$ & 7.82 & 8.20 \\
\hline $\mathrm{CO}_{3}^{--}(\mathrm{m} \mathrm{mol} \mathrm{c} / \mathrm{l})$ & 00.00 & 00.00 \\
\hline $\mathrm{HCO}_{3}^{-}(\mathrm{m} \mathrm{mol} \mathrm{c} / \mathrm{l})$ & 250.00 & 161.11 \\
\hline $\mathrm{Cl}^{-} \quad(\mathrm{m} \mathrm{mol} \mathrm{c/l})$ & 90.60 & 21.9 \\
\hline $\mathrm{SO}_{4}^{--} \quad(\mathrm{m} \mathrm{mol} \mathrm{c} / \mathrm{l})$ & 65.56 & 17.28 \\
\hline$\left(\mathrm{Na}^{+}\right) \quad(\mathrm{m} \mathrm{mol} \mathrm{c} / \mathrm{l})$ & 79.22 & 19.24 \\
\hline$\left(\mathrm{K}^{+}\right) \quad(\mathrm{m} \mathrm{mol} \mathrm{c} / \mathrm{l})$ & 107.12 & 9.79 \\
\hline$\left(\mathrm{Ca}^{++}\right)(\mathrm{m} \mathrm{mol} \mathrm{c} / \mathrm{l})$ & 67.50 & 23.00 \\
\hline$\left(\mathrm{Mg}^{++}\right)(\mathrm{m} \mathrm{mol} \mathrm{c} / \mathrm{l})$ & 21.20 & 14.80 \\
\hline SAR ratio & 8.20 & 3.16 \\
\hline $\operatorname{RSC}(\mathrm{m} \mathrm{mol} \mathrm{c/l})$ & 191.3 & 128.25 \\
\hline SSP (\%) & 43.60 & 28.79 \\
\hline TDS $\left(\mathrm{mg} \mathrm{L}^{-1}\right)$ & 546.0 & 212.0 \\
\hline${ }^{*} \mathrm{COD}\left(\mathrm{mg} \mathrm{L}^{-1}\right)$ & 80 & -- \\
\hline${ }^{\star \star} \mathrm{BOD}\left(\mathrm{mgL}^{-1}\right)$ & 68 & -- \\
\hline Total Coliform ( CFU/100 ml) & $190^{*} 10^{2}$ & 1100 \\
\hline Fecal Coliform ( CFU/100 ml) & $46^{*} 10^{2}$ & 260 \\
\hline $\mathrm{Cd} \quad\left(\mathrm{mg} \mathrm{L}^{-1}\right)$ & -- & -- \\
\hline Co $\left(\mathrm{mg} \mathrm{L}^{-1}\right)$ & 0.017 & 0.005 \\
\hline $\mathrm{Ni}\left(\mathrm{mg} \mathrm{L}^{-1}\right)$ & -- & $n d^{\star * \star}$ \\
\hline $\mathrm{Pb}\left(\mathrm{mg} \mathrm{L}^{-1}\right)$ & -- & 0.02 \\
\hline
\end{tabular}

${ }^{*}$ COD: Chemical Oxygen Demand, ${ }^{\star \star} B O D:$ Biological Oxygen Demand and ${ }^{\star \star \star}$ nd : no detected 
Table 2. Physical and chemical properties of the investigated soil.

\begin{tabular}{|c|c|c|c|c|c|c|c|c|c|c|}
\hline \multicolumn{11}{|c|}{ physical properties } \\
\hline \multirow{2}{*}{$\begin{array}{l}\text { Depth } \\
\text { (cm) }\end{array}$} & \multicolumn{3}{|c|}{$\begin{array}{c}\text { Particle size } \\
\text { distribution (\%) }\end{array}$} & \multirow{2}{*}{$\begin{array}{c}\text { soil } \\
\text { texture }\end{array}$} & \multirow{2}{*}{$\begin{array}{l}\text { SP } \\
\%\end{array}$} & \multirow{2}{*}{$\begin{array}{c}\text { Field } \\
\text { capacity } \\
(\%)\end{array}$} & \multirow{2}{*}{$\begin{array}{c}\text { Wilting } \\
\text { Point } \\
\text { (\%) }\end{array}$} & \multirow{2}{*}{$\begin{array}{c}\text { Available } \\
\text { Water } \\
(\%)\end{array}$} & \multirow{2}{*}{$\begin{array}{l}\text { Bulk } \\
\text { density } \\
\left(\mathrm{Kg} \mathrm{m}^{-}\right. \\
\left.\frac{3}{)}\right)\end{array}$} & \multirow{2}{*}{$\begin{array}{c}\text { Hydraulic } \\
\text { Conductivity } \\
\left(\mathrm{cm} \mathrm{s}^{-1}\right)\end{array}$} \\
\hline & sand & silt & clay & & & & & & & \\
\hline $0-20$ & 46.48 & 26.20 & 27.33 & \multirow{4}{*}{$\begin{array}{l}\text { sandy } \\
\text { clay } \\
\text { loam }\end{array}$} & 35.11 & 28 & 16 & 12 & 1.37 & 0.40 \\
\hline $20-40$ & 45.14 & 28.14 & \multirow{3}{*}{\begin{tabular}{|l|}
26.73 \\
27.74 \\
26.12 \\
\end{tabular}} & & \multirow{2}{*}{\begin{tabular}{|l|}
35 \\
36 \\
37 \\
\end{tabular}} & 28 & 18 & 1 & 1.36 & .36 \\
\hline $40-60$ & 46.03 & 26.24 & & & & 27 & 17 & 13 & 1.37 & 0. \\
\hline $60-1 \mathrm{~m}$ & 47.02 & 26.87 & & & 37.00 & 29 & 19 & 11 & 1.38 & 0.39 \\
\hline \multicolumn{11}{|c|}{ chemical properties } \\
\hline & \multirow{2}{*}{$\mathrm{pH}^{\star}$} & \multirow{2}{*}{$\begin{array}{c}\mathrm{EC} \mathrm{C}^{*+1} \\
\left(\mathrm{dSm}^{-1}\right)\end{array}$} & \multicolumn{4}{|c|}{ Cations (mmolc/l) } & \multicolumn{4}{|c|}{ Anions (mmolc/l) } \\
\hline & & & $\mathrm{Ca}^{++}$ & $\mathbf{M g}^{++}$ & $\mathrm{Na}^{+}$ & $\mathrm{K}^{+}$ & $\mathrm{CO}_{3}{ }^{-1}$ & $\mathrm{HCO}_{3}^{-}$ & $\mathrm{SO}_{4}^{-{ }^{-1}}$ & $\mathrm{Cl}^{-}$ \\
\hline $0-20$ & 7.87 & 1.35 & 2.82 & 3.16 & 7.77 & 0.62 & 0.00 & 4.16 & 2.99 & 7.22 \\
\hline $20-40$ & 7.89 & 0.90 & 2.10 & 2.9 & 6.51 & 0.47 & 0.00 & 3.7 & 2.10 & 6.13 \\
\hline $40-60$ & 7.95 & 0.80 & 1.73 & 2.07 & 4.39 & 0.44 & 0.00 & 3.5 & 0.81 & 3.96 \\
\hline $60-1 \mathrm{~m}$ & 7.97 & 0.97 & 2.13 & 2.69 & 5.11 & 0.48 & 0.00 & 3.79 & 1.91 & 4.71 \\
\hline
\end{tabular}

$\mathrm{pH}^{*}$ : in $(1: 2.5)$ : soil: water suspension at $25^{\circ} \mathrm{C},{ }^{\star *}$ : in saturated paste extract

$\mathrm{SO}_{4}{ }^{2-}$ was calculated by difference between cations and anions.

Microbiological properties i.e. Biochemical Oxygen Demand (BOD), Chemical Oxygen Demand (COD), Total Coliform and Fecal Coliform were determined according to the methods of APHA (1995).

\section{RESULTS AND DISCUSSION}

\section{Soil moisture distribution patterns:}

Distribution of soil moisture in soil profile, for each irrigation system with either treated wastewater or Nile water and its change with time after irrigation was represented by means of two mathematical methods. One was by constructing the Contour maps of soil moisture content with soil depth using SURFUR computer program. Contour maps of soil moisture distribution gave a wide image of how soil moisture change with soil depth. The other mathematical method was by computing the volume of soil, which include the same volumetric soil moisture content from the obtained contours. By this way, the average soil moisture content in $\mathrm{m}^{3}$ of water per unit volume $\mathrm{m}^{3}$ of soil can be derived at each soil depth for all the tested treatments. The above two methods were carried out with respect to three elapsed times from irrigation which were 2, 48 and 72 hours.

a) Contour maps of soil moisture distribution:

Soil moisture distribution pattern in soil profile either in vertical or horizontal directions can be illustrated by drawing the moisture contour lines of soil moisture contents with soil depth under all irrigation water treatments and the two systems of irrigation. The contour maps were derived using the commercial PC program SURFUR by which all the measuring points and neighborhoods can be involved in drawing the maps. Therefore, the comparison between the tested treatments can be carried out from the point of view of soil moisture distribution pattern in soil profile. Fig. 1 the represent contour maps of soil moisture distribution in soil profile for both treated 
wastewater and Nile water after 2, 48 and 72 hours from irrigation recorded by leaky pipe with subsurface drip irrigation system. The higher values of soil moisture content were observed exactly under the emitter in root zone for both the two types of water applied. In sub-surface drip system, the lateral irrigation line was buried at $25 \mathrm{~cm}$ below the soil surface. Hence, the soil profile downward this depth became wet besides the evaporation loss was not existing. Consequently, the contour maps which derived for both Nile water and treated sewage water, were approximately the same except in case of treated wastewater where the value of soil moisture content was slightly higher for all soil depths. This trend was occurred for the threeelapsed time, from irrigation. It is evident from the figure that moisture content was in sufficient value in soil profile.

Fig. 1. Contour maps of soil moisture distribution pattern in the soil profile irrigated with treated wastewater or Nile water recorded by leaky pipe emitters after 2, 48 and 72 hours from irrigation.

Fig. 2 illustrates the distribution pattern of soil moisture content in the soil profile in case of subsurface drip irrigation system with long path emitter. The presented contour maps in this Fig. showed that, there was no significant difference in the distribution patterns between treated wastewater and Nile water. However, after 2 and 48 hours from irrigation the distribution pattern lender to be the same for the two types of water. The distribution patterns for treated wastewater were more efficient applied than for Nile water. In addition, after 72 hours from irrigation a remarkable difference in soil moisture content was observed at each soil depth in the case of treated wastewater treatment. From Figs. 1 and 2 subsurface drip systems can be 
Habib, M. F. et al.

recommended to be used successfully with the two tested emitters (long path and leaky pipes).

Fig. 2. Contour maps of soil moisture distribution pattern in soil profile irrigated with treated sewage or Nile water after 2, 48 and 72 hours from irrigation recorded by Long path emitter.

b) Volumetric soil moisture distribution:

The variation of the average volumetric soil moisture with soil depth for subsurface drip irrigation system was illustrated in Figs. 3 and 4 with leaky pipe and long depth emitter, respectively. Figs. 3 and 4 indicate that the value of volumetric soil moisture content with leaky pipe increased up to $30 \mathrm{~cm}$ depth of and then decreased to with depth. In contrast, the variation of the volumetric soil moisture content with long path emitter (Figs. 3 and 4)

was increased with soil depth even to the deeper depth. Such result could be attributed to the emission uniformity of the long path emitter that is higher than that of the leaky pipes. Figs. 3 and 4 also, illustrated that, the treated wastewater gave a satisfactory behavior of the volumetric soil moisture content with soil depth. The results concluded that with the 
application of the treated wastewater by subsurface drip irrigation system with long path emitter was more efficient and recommended.

Fig. 3. Average volumetric soil moisture content (m3 water/ m3 soil )in different soil depths due to irrigation with both treated wastewater or Nile water recorded by drip irrigation system with Leaky pipes emitters after 2, 48 and 72 hours from irrigation.

4-3

Fig. 4. Average of volumetric soil moisture content $\left(\mathrm{m}^{3}\right.$ water $/ \mathrm{m}^{3}$ soil) in different soil depths due to irrigation with both treated 
Habib, M. F. et al.

wastewater and Nile water recorded by drip irrigation system with long path emitters after 2, 48 and 72 hours from irrigation. 


\section{Salts distribution patterns:}

Both movement and accumulation of the salts in soil profile are considered an acceptable measure of performance, which depends on the used system of irrigation, soil structure, texture and qualities of the applied water. The movement of salts and its distribution with depth in the soil profile could be represented with the help of contour maps of the values of soil electrical conductivity (EC), while the accumulation of salts could be represented by means of the average value of soil electrical conductivity $(E C)$ which can be measured for each soil depth.

\section{a) Contour maps of salts movement}

As presented in Fig. $\mathbf{5}$ based on the trend of salts movement using subsurface drip irrigation system with leaky pipes emitters, data indicate that Nile water gave the best movement of salts comparing with the treated wastewater. The salts moved downward with higher concentration in the case of treated wastewater from the beginning to the end of the growing season. Irrigation with Nile water resulted in decreased the amount of salts in the soil profile in addition to its decreased with time.

Fig. 5. Contour maps of soil salinity distribution $(\mathrm{dS} / \mathrm{m})$ at different times along the growing season due to irrigation with Nile and 
treated wastewater applied by subsurface drip system with leaky pipes emitter.

The tendency of salts movement in the soil profile under subsurface drip irrigation system with long path emitters is show in Fig.6. Generally, it could be noticed that applying either Nile water or treated wastewater by the abovementioned system exhibit the best and uniform movement of salts comparing with the other tested systems of irrigation. Data also, indicate that the concentration of salts in the case of treated wastewater decreased with time or approximately still constant from the beginning of the growing season to the end of growing season. The long path emitters with treated wastewater resulted in an acceptable movement of salts in the soil profile. With the application of Nile water the downward movement of salts was greatly accepted, since the concentration of salts decreased with time in addition to both the horizontal movement of salts and the reduction of electrical conductivity with soil depth for each period along the growing season. Such a finding stands in well agreement with those of Atta (2006), Hamilton et al., (2007) and Adhikari et al.,(2014) .

\section{b) Accumulation of salts in soil profile}

The variations of the average electrical conductivity with soil depth recorded for the two types of water when they applied by subsurface drip irrigation system are presented in Fig. 7. The lowest accumulated values of salts at the end of the growing season were observed with Nile water under the two tested emitters (leaky pipes and long path emitters). The value of EC reached to $1 \mathrm{dS} / \mathrm{m}$ with leaky pipes and to $0.9 \mathrm{dS} / \mathrm{m}$ with long path emitter. It was also observed that with Nile water under long path emitter, the value of EC reached to $0.5 \mathrm{dS} / \mathrm{m}$ for depth of $30 \mathrm{~cm}$ at the end of the growing season and then increased to $0.6 \mathrm{dS} / \mathrm{m}$ at the deeper depths. With treated wastewater, the salts accumulated gradually showing an increase from the beginning to the end of the growing season. The value of EC reached 1.3 $\mathrm{dS} / \mathrm{m}$ under leaky pipes while it remains constant at $1.2 \mathrm{dS} / \mathrm{m}$ for long path emitters. This was occurred at the surface layer of the soil profile. 
Fig. 6. Contour maps of soil salinity distribution in $(\mathrm{dS} / \mathrm{m})$ at different times along the growing season due to irrigation with Nile and 
treated wastewater applied by subsurface drip system with long path emitter.

Fig. 7. Average electrical conductivity (EC) with soil depth recorded at the three different times along the growing season due to irrigation with Nile and treated wastewater applied by subsurface drip irrigation system (leaky pipes and long path emitters).

Irrigation system and the situation of salts in soil profile:

The suitable irrigation system for the proper application of the treated wastewater is the system, which distributes water uniformly and consequently decreases the accumulation of salts in the soil profile. As for mentioned when w subsurface drip irrigation system as used with the two types of emitters (leaky pipes and long path), the accumulation of salts decreased with as time as illustrated in Fig.(8), which indicate that there was no significant difference in the accumulation of salts between the two types of the used emitters. Also, the value of EC was approximately equal to $1 \mathrm{dS} \mathrm{m}^{-1}$ after ten months for both leaky pipes and long path emitters. Fig. 9 represents from the empirical equation for predicting the elapsed time before soil degrade. However, applying treated wastewater with leaky pipes emitters will cause a soil failure after about 31 years. This time was 24 years with long path emitters. Consequently, the obtained results recommended that using subsurface drip irrigation system with leaky pipes emitter was more suitable system for soil irrigation with treated wastewater. However, long path emitters can be used 
with subsurface irrigation system for applying treated wastewater due to its higher distribution uniformity without any hazard effect on soil.

Fig. 8. Accumulation of salts in soil profile with time in the soil irrigated with the treated wastewater under sub-surface drip irrigation system. 
Fig. 9. Elapsed time (years) before soil degrade according to allowable value of electrical conductivity for sub-surface drip irrigation system using treated wastewater.

Effect of water source and irrigation system on Bermuda grass height and intensity:

Both of plant height and intensity were considered the two parameters for express the response of Bermuda grass to the applied water and the used irrigation system. The height of Bermuda grass and its intensity were measured every week during the interval between two consecutive mowing. Mowing process was conducted every month through the growing season and the average values of plant height and intensity were recorded and listed in Table 3.

Table 3 represents the average Bermuda grass height and intensity between two consecutive mowing under subsurface drip irrigation system for both treated wastewater and Nile water. Both grass height and intensity were increased with increasing time after cutting. The highest grass increased from $0.06 \mathrm{~m}$ at 0 day to $0.133 \mathrm{~m}$ and 0.11 after 28 days under subsurface drip irrigation system (leaky pipe) when grasses were irrigated with treated wastewater and Nile water, respectively, where the values of increasing percentage for the above mention sources of water were 121.67 and 83.33 $\%$, respectively. Under long path emitter, values of grass height increased from $0.06 \mathrm{~m}$ to $0.125 \mathrm{~m}$ and $0.103 \mathrm{~m}$ for both treated wastewater and Nile water with increate percentages of 108.33 and $71.67 \%$, respectively. Data also, indicate that grass intensity $\left(\mathrm{Kg} / \mathrm{m}^{2}\right)$ was increased from 1.3 and 0.80 under leaky pipe to 2.65 and $1.37 \mathrm{Kg} / \mathrm{m}^{2}$ with increment percentage of 103.85 and $71.25 \%$ for treated wastewater and Nile water, respectively. These values under long path emitter increased from 1.19 and 0.73 to 2.49 and 1.29 with increment percentage of 109.24 and $76.71 \%$, respectively. It is worthy to mention that treated wastewater showed higher values in increasing percentage of grass height and intensity than those obtained with Nile water under both leaky pipe and long path emitter. Therefore, from the point of view, subsurface drip irrigation systems could be successfully used with the treated wastewater as a good source of Bermuda grass irrigation.

Table 3 . Average of Bermuda grass height and intensity as affected by sources of irrigation water under subsurface drip irrigation systems.

\begin{tabular}{|c|c|c|c|c|c|c|c|c|}
\hline \multirow{3}{*}{$\begin{array}{c}\text { Time after } \\
\text { cutting } \\
\text { (days) }\end{array}$} & \multicolumn{4}{|c|}{$\begin{array}{c}\text { Subsurface drip system } \\
\text { (leaky pipe) }\end{array}$} & \multicolumn{4}{|c|}{$\begin{array}{l}\text { Subsurface drip system } \\
\text { ( long path emitter) }\end{array}$} \\
\hline & \multicolumn{2}{|c|}{$\begin{array}{c}\text { Treated } \\
\text { wastewater }\end{array}$} & \multicolumn{2}{|c|}{ Nile water } & \multicolumn{2}{|c|}{ Treated wastewater } & \multicolumn{2}{|c|}{ Nile water } \\
\hline & $\begin{array}{l}\text { plant } \\
\text { height } \\
\text { (m) }\end{array}$ & $\begin{array}{c}\text { Plant } \\
\text { intensity } \\
\left(\mathrm{kg} / \mathrm{m}^{2}\right) \\
\end{array}$ & $\begin{array}{c}\text { plant } \\
\text { height } \\
(\mathrm{m})\end{array}$ & $\begin{array}{c}\text { Plant } \\
\text { intensity } \\
\left(\mathrm{kg} / \mathrm{m}^{2}\right)\end{array}$ & $\begin{array}{l}\text { plant } \\
\text { height } \\
\text { (m) }\end{array}$ & $\begin{array}{c}\text { Plant } \\
\text { intensity } \\
\left(\mathrm{kg} / \mathrm{m}^{2}\right) \\
\end{array}$ & $\begin{array}{l}\text { plant } \\
\text { height } \\
(\mathrm{m})\end{array}$ & $\begin{array}{c}\text { Plant } \\
\text { intensity } \\
\left(\mathrm{kg} / \mathrm{m}^{2}\right) \\
\end{array}$ \\
\hline 0 & 0.06 & 1.30 & 0.06 & 0.80 & 0.06 & 1.19 & 0.06 & 0.73 \\
\hline 7 & 0.088 & 1.70 & 0.06 & 0.75 & 0.085 & 1.69 & 0.063 & 0.79 \\
\hline 14 & 0.107 & 2.10 & 0.077 & 0.96 & 0.104 & 2.07 & 0.075 & 0.93 \\
\hline 21 & 0.12 & 2.40 & 0.086 & 1.07 & 0.115 & 2.28 & 0.081 & 1.01 \\
\hline 28 & 0.133 & 2.65 & 0.11 & 1.37 & 0.125 & 2.49 & 0.103 & 1.29 \\
\hline Percent of & 121.67 & 103.85 & 83.33 & 71.25 & 108.33 & 109.24 & 71.67 & 76.71 \\
\hline
\end{tabular}


lincreasing (\%)

Thus it can be concluded that the re-use of treated wastewater for landscaping under drip irrigation system have a positive impact on the growth of grass Bermuda. Furthermore, you can use a drip irrigation system in the subsurface landscape irrigation, taking into account the regulations and conditions the environment and health in the Egyptian Code No. 501 of 2005.

\section{REFRENCES}

Abou-El-Soud, H. M. A. (2009). Studies on water and salt movement under surface and drip irrigation systems in Nile Delta soils. M. Sc. Thesis Fac., of Agric. (Soils) Mansoura Univ., Egypt.

Adhikari P., Manoj K. S., John G. M. and David D. (2014). Irrigation with Treated Wastewater: Quantification of Changes in Soil Physical and Chemical Properties. Irrigat. Drainage Sys. Eng. 3(1): 2-10. http://dx.doi.org/10.4172/2168-9768.1000117

American Public Health Association (APHA); American Water Works Association and Water Pollution Control Federation (1995). Stander Methods For the Examination Water and Wastewater, American Public Health Association, Washington, DC. 20005.

American Society of Agricultural Engineering (ASAE). (2005). ASAE standards engineering practices data. $43^{\text {rd }}$ edition: 864. Michigan., ISBN 1892769476

Atta Y. M. M. (2006).Reue of Treaed Sewage Water Under Sprinkr and Drip Irrigation Systems. Ph.D. Thesis, Fac. of Agric., Minufiya Univ. Egypt.

Egyptian Code principles (ECP) (2005). Re-use of treated Wastewater in agriculture. Housing and Building National Research Center, Ministry of Housing and Urban Communities, Issued Decision No. 501, in February 2005 ( in Arabic).

El-Zaemey, A. K. (1992). Wastewater Reuse Practices in Yemen, Proceeding of the National Seminar on Wastewater Reuse, Faculty of Engineering, Sana'a University, Republic of Yemen.

Hamilton, A. J., Stagnitti F., Xiong X., Kredil S.L., Benke K.K., Maher, P. (2007).Wastewater irrigation: The State of Play. Vadose Zone J. 6: 823-840.

Holy, M. (1971). The Influence of Irrigation and Drainage on the Environment with Particular Emphasis on Impact on the Quality of Surface and Ground Waters, Water and Environment, Rome, FAO , Irrigation and Drainage Paper 8.

Klute, M. 1986." Methods soil analysis". Part 1. Physical and Mineralogical Methods $2^{\text {nd }}$ Ed. American Society of Agronomy, Inc., Soil Sci. Soc. of Ame., Inc Madison, Wisconsin, USA., 399 - 404.

Page, A. L., Miller, H. and Keeney, D.R. (1982). "Methods of Soils Analysis". Part-2: Chemical and Microbiological Properties $\left(2^{\text {nd }}\right.$ ed.). Amer. Soc. of Agron., Madison, Wisconsin, USA. 
Qadir, M. D.; Wichelns, L.; Raschid Sally, P. S.; Minhas, P. ;Drechsel, A.; Bahri, P. and McCornick .(2007). Agricultural use of marginal quality water- opportunities and challenges ,IWMI Part 4 Ch8 final.

Shock, C.C. (2007). Subsurface drip irrigation for seed production of intermountain forbs. Native Wildflower Seed Production Symposium, Orlando, Florida July 19-20.]

Trenton, L. R., Scott, A. W., Arthur, W. W. and Thomas, L. T. (2008). Tape depth and germination method influence patterns of salt accumulation with subsurface drip irrigation. Agric. Water Management 95(6):669-677.

http://www.sciencedirect.com/science/article/pii/S0378377408000206

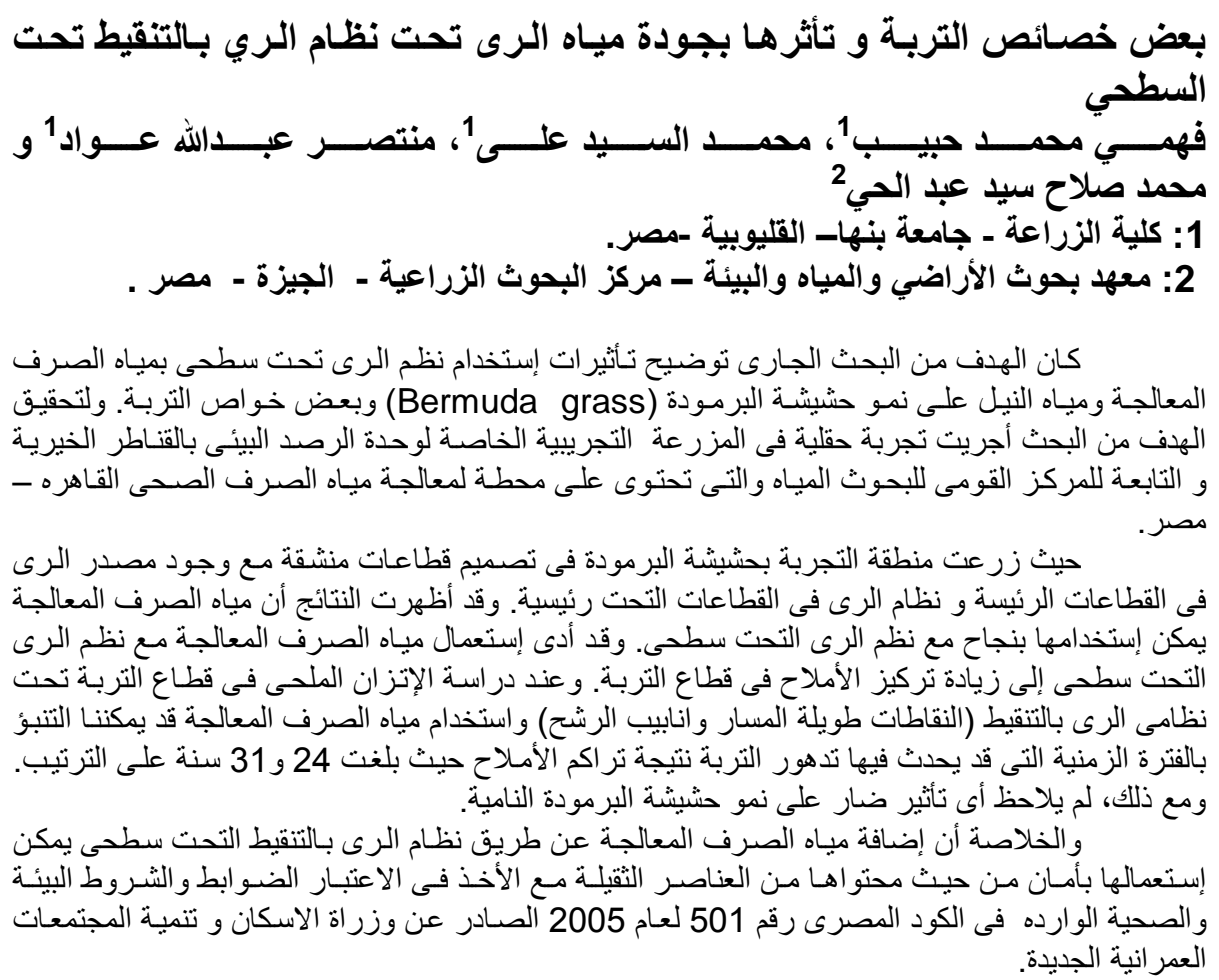

